\title{
The University of Texas at Austin \\ Department of Chemical Engineering and Center for Polymer Research
}

来山尚之*

The University of Texas at Austin, Center for Polymer Research (CPR) は, その名のごとく, 米国テキサス (州 立) 大学オースチン校の Chemical Engineering Department（図 1）内に設置された研究機関である。テキサス 大学は日本人にはあまり馴染みのある大学ではないが, Houston/Galveston (医学系学部が集中), San Antonio ( ラモの砦, プロバスケットボールチーム NBAの San Antonio Spursの本拠地), El Paso (メキシコ国境部), Dallas /Arlington (ダラス近郊), Brownsville（テキサス州最南 部）などの州内主要都市は言うに及ばず，州内全域に関連 施設を有する巨大教育機関である，中でもオースチン校は その中心で，広範な分野を網羅した学部学科群に約 5 万人 の学生, 約 3 千人の教員とそれをサポートする約 1 万 7 千 人のスタッフが所属するマンモス大学である (図 2)。そ の教育水準は高く, 全米の大学ランキングに扔いて, Chemical Engineering Department $の$ graduate school は トップ 10 の常連となっている（学部, 学科によってラン キングは異なります).

オースチン市はテキサス州のほぼ中央部に位置する人口 約 65 万（2000 年現在）の州都であり, 治安も良い.テキ サスと言えば，日本人には広大な西部砂漠のイメージが強 く，年間を通じて晴天の日が多いのも事実であるが（年間 約 300 日が晴天と言われている), 砂漠が始まるのはオー スチンから西へ車で数 100 マイルも走った辺りからである。 実際に生活してみると, ビジネ久, 文教施設, そして自然 が調和するとても住みやすい街であった。

テキサス州がオイルビジネスで閏っていることは周知の 事実だが，現在，オースチン市には IBM，Dell 等のコン ピューターメーカー, 韓国半導体メーカー, 日本の半導体 製造機器メーカー等, 時代の最先端産業が進出し, 急速な 国際化が進んでいる。この現状に，1999 年夏にはそれま での国内線専用空港が閉鎖となり，新しく国際空港が開港 された.オースチンは今, 国際都市として着実に発展して きている．因みに，私が滞在した 2 年間（1997-1999）は 現米国大統領の George W. Bush 氏が州知事を務めていた 時代でもあり, 大統領選挙前後には, テキサス州やオース

\footnotetext{
* Kitayama, Naoyuki

三菱ガス化学(侏) 東京研究所

東京都葛飾区新宿 6-1-1（T125--0051）

2001. 10.22 受理
}

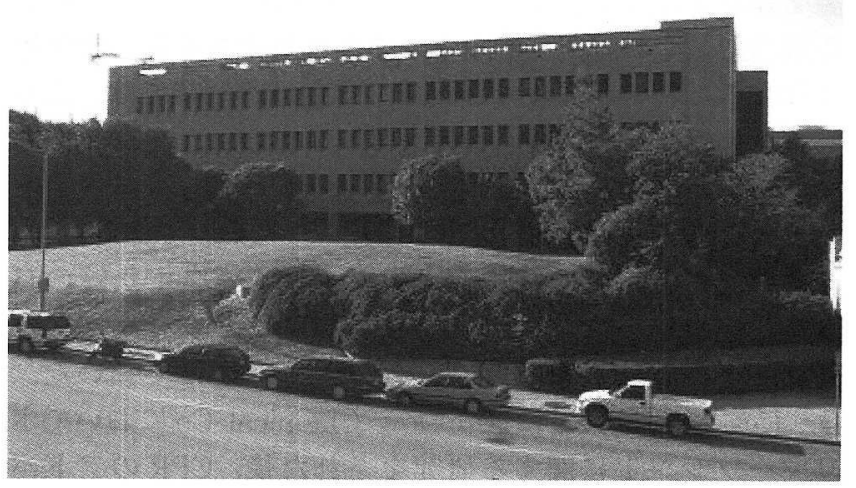

図 1 CPR 全景

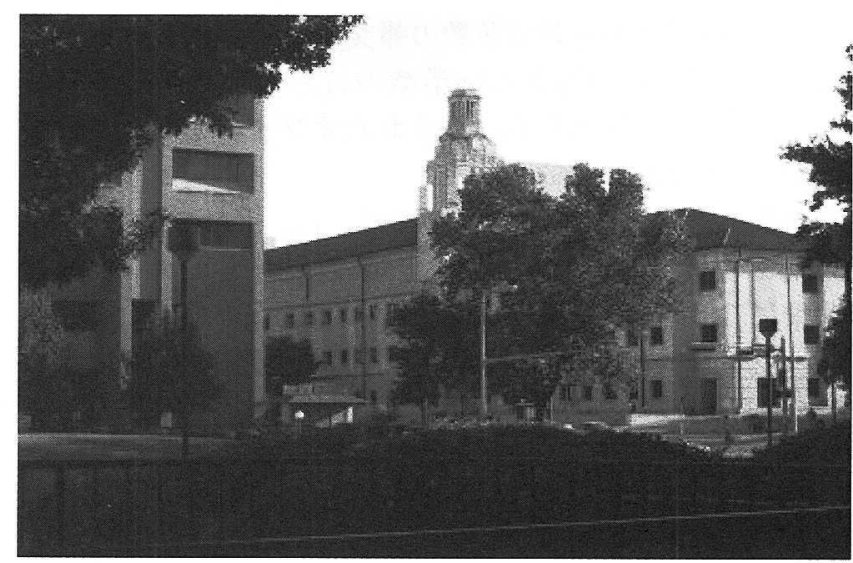

図 2 CPR 前からテキサス大学オースチン校のシンボル タワーを望む

チン市から全米，世界へと映像が発信されていたことは記 憶に新しい.

さて，前置きが長くなったが，ここで CPRに話を戻し たい。私が CPRに在籍していたのは今から約 2 年前の 1999 年 8 月迄であり, また当時の記憶をべースに本稿を 執筆させて頂いているため，必ずしも up-to-date な内容に はなっていない可能性があることを初めにお許し頂きたい。 また, 私が在籍していたのが, 後に紹介する Dr. D. R. Paul 教授の研究室であったことから, 紹介はDr. Paul 研究室 の内容を中心とさせて頂いた。 


\section{1 . 研究室の構成}

CPR を統括するのは，ポリマーブレンドの世界では第 1 人者とされる Dr. Donald R. Paul 教授である. 改めて紹介 するまでもないのだが，Dr. Paul 教授は論文投稿数 500 報 を超え, Industrial \& Engineering Chemical Researchの editorを務められたり，最近も著書 “Polymer Blends (John Wiley \& Sons Inc., Dr. Clive B. Bucknall との共 著)”を発刊されるなど, 広範に亘って精力的な活躍をさ れている.また, Phillips Award in Applied Polymer Science, ACS (1984), Outstanding Achievements Award in Research, Society of Plastics Engineers (1982), Society of Plastics Engineers International Award（1993）を始め, 数々の賞を受賞されている.Dr. Paul 教授の研究に対する 姿勢は非常に慎重, 正確, そして厳しく, 投稿論文や学位 論文等が完成に至るまでには，データの確認作業と徹底的 な議論に多くの時間を費やす。このプロセスを経て学生達 は研究者として鐉えられる訳で, そういう意味では, この 厳しさはむしろ「親心」とでも呼べようか. 一生懸命努力 する学生, ポスドクには時間を惜しまず親身になってアド バイスを与えてくれる姿勢は，極めて“fair”である。

多忙な Dr. Paul 教授を補佐し, 学生・ポスドク達の良 き相談相手となっているのがアドバイザーの Dr. Keskkulaであり，私も滞在中には随分と助けて頂いた。

Dr. Keskkula は長年に亘り Dow Chemical Co.においてポ リマーブレンドに関する研究をされた後, CPRのアドバ イザーとなられた方であり, その功績は出願された特許等 からも推し量ることが出来る. CPR 着任後も, Dr. Paul 教授，学生等との共著で多数の報文を発表されている. Dr. Keskkulaは, その輝かしい業績の持ち主らしからぬ気さ くな紳士で，家族の写真に囲まれたオフィスで然々と仕事 をしている姿が印象的だった。

CPR を支えるその他の教授陣は，Dr. Koros 教授，Dr. Barlow 教授などである. Dr. Paul 教授から頂戴した最新 情報によれば，Dr. Koros教授はGeorgia Institute of Technology へ移られるため, 現在は研究室の移転作業に お忙しいとのことである.一方, Dr. Barlow 教授も，こ の semesterを最後に大学を退職される（12月末）とのこ とで, 顔見知りの教授陣が CPR を去られるのは, 筆者に は少々寂しく思える。

Dr. Koros 教授と Dr. Balow 教授の後を引き継ぐため, North Carolina State University から Dr. Benny Freeman 氏が教授として, Lucent から Dr. Lynn Loo 氏が助教授と して，それぞれ 1 月，9月に赴任される. Dr. Freeman 氏 は日本の研究者の間でも著名な高分子膜の権威で, 研究分 野はほほDr. Koros 教授と同じである.一方, Dr. Loo 氏 は Princeton University (Chemical Engineering) でブロッ クコポリマーの研究成果により Ph.D を取得した後, Lucent でポスドクとして研究を続けられた方である. CPR での研究の詳細は依然決まっていないようであるが, 彼女 の Lucentでの経験を考慮すれば, エレクトロニクスや フォトニクスの分野における高分子材料の利用研究を行う ことは間違いないだろう。

実験は, 大学院生とポスドクを中心としたチームにより
遂行されている. 出入りの多い短期の交換留学生等を除い ても, 筆者の滞在中, 常時大学院生は 10 人前後, ポスド クが $2 \sim 3$ 人，筆者を含む客員研究員が $1 \sim 2$ 人程度と，一 つの研究室としては大変な大所帯であった．また，その国 籍も米国人を初め, 日本人, 韓国人, 中国人, インド人, タイ人，ブラジル人等と多様であった。これらのメンバー がCPRにおける研究の 2 本柱であるI）ポリマーブレン ドと II）高分子膜のチームに分かれ，日々研究に励んでい た. 日本の大学とは異なり, 研究室にはいわゆる学部学生 は在籍せず，また助手に当たるポストの職員もいないため， 実質的にポスドクが大学院生の身近なアドバイザーになっ ている。研究に関しては, 学生間, 学生・ポスドク間での 議論も活発で, 研究室の黑板にはいつもその名残があった。

\section{2. 研究機器等}

\section{I ）ブレンドの調製・試験片成形}

主な混練装置としては Brabenderの他，単軸・二軸の 押出機がある。また, 強度評価用の試験片を成形するため, 圧縮成形機と射出成形機が整備されている。

\section{II ) 強度等の测定}

Instron 引張試験機, Izod 衝撃試験機, Dynatup 試験装 置, 動的粘弾性測定装置等が備えられている。また, Izod 衝撃試験機には温調器が具備されており, $-60^{\circ} \mathrm{C} \sim 80^{\circ} \mathrm{C}$ の範囲における測定が可能となっている.

III ) 気体分離膜, 浸透気化分離膜関連の機器

主な装置として，気体透過率測定装置，気体収着量測定 装置, パーベーパレーション装置, 水蒸気透過率測定装置, 水蒸気収着量測定装置等がある。

IV) その他

共通機器として, DSC, TG-DTA, DMTA, FT-IR, NMR, エリプソメーター, 広角 $\mathrm{X}$ 線回折, 走查型電子顕微鏡 $(\mathrm{SEM})$, 透過型電子顕微鏡 (TEM), マイクロトームな どがある.また，ブレンドの粒径（分布）解析等のための 解析ソフトも活用されている.

1 人当たりのスペースは広く（図 3 ), $5 \mathrm{~m} \times 8 \mathrm{~m}$ 位の居室 兼実験室を 2 人で使用する.勿論, メンバーは相互に各部屋 の機器を使用するので, 人の出入りは結構激しい.この他に, 大型の機器類をまとめて設置した大実験室があり,予約さ え取っていれば,メンバーは自由に使用することが出来る.

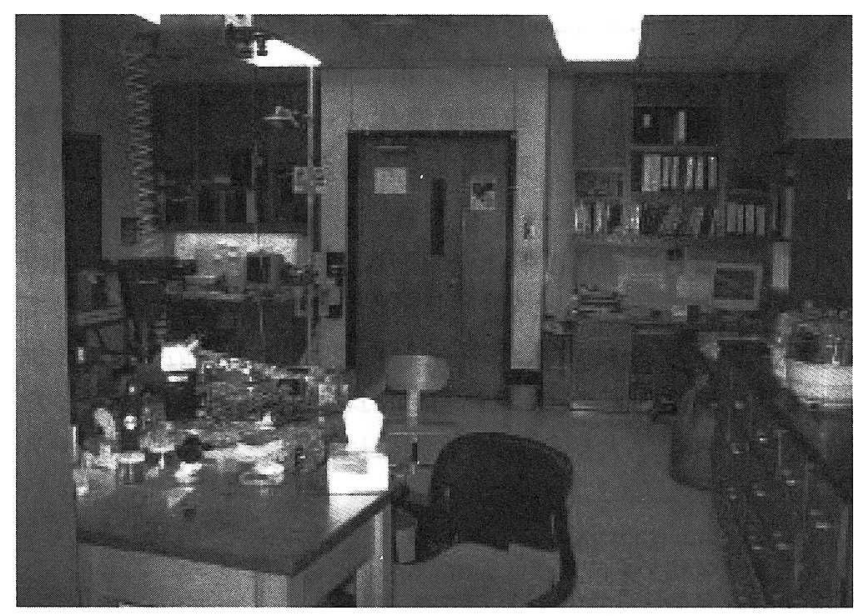

図 3 広い居室兼実験室 


\section{3. 研究トピックス}

CPR の研究テーマは, 大きく分けて I ）ポリマーブレ ンド/アロイ, およびII）高分子膜のガスバリヤ性や気体 分離膜としての機能等に関する研究, の 2 本柱からなって いる. これらの研究の第一目標は, ポリマーの特性や様々 な挙動とポリマー構造の関係を明らかにしたり, ポリマー に関する molecular engineering の基礎を確立することに ある、また，ポリマーブレンドやポリマーアロイ，高分子 膜関連の研究においては，ポリマーの調製方法についての 検討も重要な項目であると捉えている.

実験対象となる系は広範に亘るが，その中でも最近はポ リアミド, ポリカーボネート, ポリアクリレート, ポリエ ステル等をベースとするポリマーについて精力的に検討を 行っている.

I ）ポリマーブレンド

ポリマーブレンドに関する研究では, ブレンドのモルホ ロジー形成過程を観察したり，ブレンドされたポリマー間 の熱力学的な相互作用を定量的に解析することを行ってい る. 具体的には, 示差走查熱量測定 (DSC), 動的粘弾性 測定 (DMA), 光散乱法, 混合熱測定, PVT 挙動測定な どに代表される実験的手法と, Flory-Huggins, SanchezLacombe, binary interaction model, molecular mechanics などの理論を組み合わせて解析を行っている. 非相溶の混 合系における第一の興味は, そのブレンドがどの様なモル ホロジーを形成するかということと，これら非相溶ポリ マー間の界面状態の解析にある.この分野における研究の 多くは，あらかじめ調製しておくか，若しくは混合中の熱 等によって生起される化学反応により in-situで形成され るブロック,ないしグラフトコポリマーを使って, ポリマー /ポリマー界面をコントロールし，機械強度に優れた素材 を作り出すことにある，ブレンドのモルホロジーや強度試 験等による破壊面の観察では, 透過型電子顕微鏡（TEM） や走査型電子顕微鏡（SEM）を活用している，また，強 度の評価に際しては, 温度, ノッチ形状, 破壊速度等のファ クターとの相関性も調べている.

最近の代表的な研究成果は, 以下の報文にまとめられて いる.

- "Thermodynamics of solubilization of functional copolymers in the grafted shell of core-shell impact modifiers : 1. Theory, " Polymer, 37, 115 (1996) (with M. Lu).

- "Impact modified nylon 6/polypropylene blends : 3 . Deformation mechanisms, "Polymer, 36, 4621(1995) (with A. Gonzalez-Montiel and H. Keskkula)

- "Blends of glycidyl methacrylate/methyl mechacrylate copolymers with poly (vinylidene fluoride), J. Polym.
Sci.: Part B: Polym. Phys., 33, 1693 (1995) (with P.P. Gan) II) 高分子膜

高分子材料におけるガスの溶解性と拡散性の評価を通じ て，ガスバリヤ材料や分離膜としての応用を目指している. 研究の中心は，高分子材料を構成する分子の主鎖，側鎖等 の分子構造が，高分子膜の分離特性とどの様に関係してい るかを明らかにすることにある．この過程では，新規ポリ マーの開発や, 既存ポリマーの化学修飾なども行っている. 他の研究者と共同で進めている Separations Research Program（SRP）では，現在，すでに工業現場で利用され ているガス分離システムよりもさらに生産性が高く，選択 性に優れ，そして信頼性の高い高分子膜の開発を目指して いる.

気体分離膜，浸透気化分離膜（Pervaporation）に関す る研究は, 歴史的には, PC, PSF, PAr 系の気体透過性・ 分離性と膜構造の関係を研究してきた．現在は，主に薄膜 における物理エージング挙動について研究している. パー ベーパレーション分離では, 芳香族/脂肪族の透過性・分 離性とアクリレート系架橋膜あるいはポリイミド系膜の構 造と特性の関係について研究している.

最近の代表的な研究成果は, 以下の報文にまとめられて いる.

- "Polymer-polymer interactions," Pure \& Appl. Chem., 67, 997 (1995)

- "Gas transport properties of polyarylates: Substituent size and symmetry effects, " Macromolecules, 28, 8277 (1995) (with M.R. Pixon)

III) トピックス

Dr. Paul 教授にご提供頂いた最新情報によると，最近は， ナノコンポジットに関する研究の占める割合が高くなって きているとのことである. 現在, 4 人の大学院学生と 1 人 のポスドクが, ナノコンポジットの調製とその特性評価に 携わっている. マトリクスとして，ポリアミド，ポリカー ボネート, PBT, SANなどを選択し, clayはAustinか ら車で約 1 時間の町にある Southern Clay Productsから 供給されている. Southern Clay Productsは, clayの代 表的サプライヤーとしてご存知の方も多いと拝察する. CPR では, Southern Clay Products との共同実験の形で 約 3 年前から精力的にナノコンポジットに取り組んでいる.

\section{4. おわりに}

今回の執筆に際し, CPR の Dr. D. R. Paul 教授から最新 情報を頂戴し，内容の校正を頂いた。 また，CPRで同時 期を過ごし, 良き友人である静岡大学工学部物質工学科助 手の松井誉敏氏には, 特に高分子膜の研究内容ついて助言 と校正を頂いた。ここに感謝を申し上げます. 